\title{
EFFECT OF GARLIC EXTRACT ON PHYSIOLOGICAL AND BIOCHEMICAL PARAMETERS OF RHAMDIA QUELEN AND THEIR RESPONSE TO AN INFESTATION WITH ICHTHYOPHTHIRIUS MULTIFILIIS
}

\author{
AMORIN, D.G. ' ; NUNES, M.A. ' ; ROMÃO, S. '; RAMOS, C.J.R. '; CAZAROLLI, L.H. ' * \\ 'Universidade Federal da Fronteira Sul, Campus Laranjeiras do Sul \\ *Corresponding author: luisacazarolli@uffs.edu.br
}

\begin{abstract}
Amorin, D.G..$^{*}$, Nunes, M.A. ${ }^{2}$, Romão, S. ${ }^{3}$, Ramos, C.J.R. ${ }^{4}$ \& Cazarolli, L.H. ${ }^{5}$ (2019). Effect of Garlic extract on physiological and biochemical parameters of Rhamdia quelen and their response to an infestation with Ichthyophthirius multifiliis. Braz. J. Aquat. Sci. Technol. 23(1). eISSN 1983-9057. DOI: 13470/bjast.v23n1. The aim of the study was to investigate the effect of garlic extract on hematological, immune and metabolic systems of Rhamdia quelen juveniles and the animals's resistance to Ichthyophthirius multifiliis. The fishes were fed twice daily during 77 days with diets containing $0 \%, 0.5 \%, 2.5 \%$ and $5 \%$ of garlic extract. After that, half of the animals of each treatment were submitted to the challenge with the parasite I. multifiliis, maintaining the diets. The other half of the animals were maintained in the original system receiving the dietary supplementation. The use of garlic extract in the diet did not promote significant changes in glycaemia, hepatic glycogen content, tissue and plasma aminotransferase activities, and tissue lipid peroxidation levels. On the other hand, it stimulated the synthesis of muscle glycogen and promoted a reduction of hepatic catalase activity. In terms of hematological and immune systems, the use of garlic extract increased the number of red blood cells, but reduced hemoglobin content. Furthermore, it was not able to change the total number of leukocytes and thrombocytes, but it promoted an increase in the number of basophils and reduced the monocyte count of the animals. The dietary supplementation with garlic extract did not act as a growth promoter for silver catfish juveniles, did not influence the basal metabolic homeostasis, immune or hematological responses of the fishes and did not improve the resistance to the infestation with the I. multifiliis in the concentrations and periods studied.
\end{abstract}

Key Words: Ichthyophthirius multifiliis, Garlic Extract, Hematology, Biochemistry, Rhamdia quelen.

\section{INTRODUCTION}

Global fish production has been growing in the last five decades with food fish supply increasing at an average annual rate of $3.2 \%$ expanding from 32.4 million to 66.6 million tons between 2000-2012 (FAO, 2014). Although this prominent scenario, world aquaculture production is vulnerable and an increase of disease outbreaks has been reported due to culture intensification, resulting in partial or total loss of production, representing an important limiting factor in the progressive growth of aquaculture industries (Raja \& Jithendran, 2015). The intensive system of cultivation induce damages on fishes' immune responses and reduce the ability to fight against pathogens giving them the opportunity to proliferate causing serious health issues (Raja \& Jithendran, 2015). Among the several pathogens, parasitic outbreaks act as an important limiting factor for aquaculture businesses, especially Ichthyophthiriasis, commonly known as 'white spot disease' caused by I. multifiliis in freshwater fish worldwide. Usually, I. multifiliis invades the epithelium of skin and the gills of the hosts, causing damage in the parasitic sites. Because of the economic significance of this disease, great efforts have been done to control ichthyophthiriasis, including finding effective drug treatments and immunoprophylactic methods (Wei et al., 2013). The current available treatments are administered regularly as additives in fish food or sometimes in baths or injections and can be used as prophylactics (prevent diseases before they occur) or therapeutics (treat sick animals) (Rico et al., 2013). Nevertheless, the use of veterinary drugs is becoming more restricted since they have negative impacts on the environment as well as on animal and human health safety. Considering that, there has been a growing interest in screening alternative methods that could maximize fish immunity to avoid and face pathogen infections (Raja \& Jithendran, 2015). Among them a wide range of medicinal plants show potential effects on growth and survival of aquatic organisms (Hai, 2015). Among these, garlic, Allium sativum L. (Shakya \& Labh, 2014) can be administered either as therapeutic baths or as dietary supplements. Garlic has been reported to have antioxidant, antimicrobial, antifungal, antiviral and antiparasitic effectsand to improvethe immunesystem(Lawson, 1998). Earlier studies have reported that garlic, as a fish feed additive, may stimulate growth, improve antioxidant status and enhance immunological, hematological and serum biochemical parameters. Additionally, it has been proven efficient in controlling pathogens such 
as bacteria, parasites and fungi in different freshwater fishes (Shakya \& Labh, 2014; Buchmann et al., 2003; Lee \& Gao, 2012).

Although there have been studies showing the potential use of garlic in aquaculture, few researches have been carried out concerning these activities against fish pathogenic parasites, especially in native species, such as $R$. quelen (silver catfish). Despite being considered a promising species for commercial use, $R$. quelen is very sensitive to environmental changes, especially considering intensive fish farming models, which affects its immune and metabolic systems and its ability to respond to stress increasing the spread of opportunistic pathogens and diseases. Taking these into account, the objective of this study was to investigate the effect of garlic extract as a feed additive on hematological, immune and biochemical parameters of $R$. quelen as well as its effects in relation to immune responses and disease resistance to Ichthyophthirius multifiliis.

\section{MATERIAL AND METHODS}

\section{Plant material}

Garlic (Allium sativum) extract ( $0.5 \%$ of allicin) was purchased from a commercial source (Active Pharmaceutics, São José, SC, Brazil).

\section{Water quality}

Water $\mathrm{pH}$, dissolved oxygen and salinity in the tanks were measured daily using a YSI oxygen meter (Model Y5512; YSI Inc., Yellow Springs, OH, USA). Ammonia levels were determined daily while nitrite levels were monitored each 15 days using commercial kits (Alfa kit). The recirculation system of water aquaria was maintained with water added with $\mathrm{NaCl}(2 \%)$.

\section{Experimental animals}

Eighty silver catfish juveniles $(8.5 \pm 0.7 \mathrm{~cm}$ and $9,55 \pm 2.1 \mathrm{~g}$ ) were obtained from a commercial fish farmer (Akna Alevinos, Toledo, PR, Brazil). These juveniles did not present any apparent illness when they arrived at the Fish Pathology Laboratory, at Universidade Federal da Fronteira Sul, Laranjeiras do Sul, PR, Brazil.

The fishes were randomly distributed in a continuously aerated $46 \mathrm{~L}$ tanks system, where they were maintained for a seven days' acclimation period. After this period, the juveniles were submitted to the supplementation experiment. Dead fish were removed daily. The feeding and swimming behavior of the juveniles were continuously observed throughout the acclimation and experimental periods.

The laboratory temperature was maintained by using an air conditioner $\left(29^{\circ} \mathrm{C}\right)$. All the ani- mals were monitored carefully and maintained in accordance with the ethical recommendations of the Brazilian Veterinary Medicine Council and the Brazilian College of Animal Experimentation. (Protocol CEUA/232055.004131/2015-50).

\section{Diets}

During the acclimation period, the juveniles were fed twice a day (08:00 am and 05:00 pm) with a commercial diet (Algomix, 32\% crude protein, AlgomixAgroindustrial Ltda, Ouro Verde-PR, Brazil) until apparent satiety. Uneaten food as well as other residues and feces were siphoned out 30 min after feeding. During the experimental period, the animals received the commercial basal diet (crude protein $32 \%$ ) that was divided into four parts that were sprinkled with water (control) or different concentrations of garlic extract solution $(0.5,2.5$ or $5 \%)$. After sprinkling, the different diets were air-dried and stored at $4{ }^{\circ} \mathrm{C}$ for the feeding experiment (Shalaby et al., 2006; Bard et al., 2006).

\section{Feeding experiment}

Eighty silver catfish juveniles were acclimatized for seven days, and then divided into four equal groups $(n=20)$. The first group (C) was fed with the control diet (diet free from garlic extract). The second group (T1) was given the basal diet containing $0.5 \%$ garlic extract. The third group (T2) was given the basal diet containing $2.5 \%$ garlic extract and the fourth group (T3) was given the basal diet containing $5 \%$ garlic extract. The fish were hand-fed twice daily until apparent satiety. The water quality of the aquaria was monitored daily. At the beginning and at the end of the experiment, it was performed a biometry measuring total weight, total length and standard length of the animals.

\section{Challenge test}

After 77 days of the feeding experiment, 10 fish from each group were transferred to a new continuously aerated $46 \mathrm{~L}$ tanks system in an ar-conditioned room $\left(22^{\circ} \mathrm{C}\right)$ and divided into four subgroups (10 fish distributed in 4 aquaria) for the challenge test with I. multifiliis. The water quality parameters were monitored daily. The other animals ( $n=10$ for each group) were maintained in the original system receiving the specific treatments during the challenge test period. After acclimation (24h) the fish were infested by subjecting them to a temperature stress (transferred from $27^{\circ} \mathrm{C}$ to $10^{\circ} \mathrm{C}$ for $7 \mathrm{~min}$, then maintained at $17^{\circ} \mathrm{C}$ for $24 \mathrm{~h}$ and after that transferred to $23^{\circ} \mathrm{C}$ ) and repeated this protocol four days later. Additionally, one silver catfish juvenile infested with I. multifiliis was added in each aquarium and maintained during the challenge period. The animals 
presented the first white spots after five days of the temperature stress and were followed by an additional period of four days. During this period the animals continued to receive the specific treatments. Mortality rate for all groups of challenged fish was calculated from the number of dead fish removed from each tank throughout the challenge experimental period (Souza et al., 2001).

\section{Tissues and blood sampling}

At the end of the feeding experiment (86 days) both, unchallenged and challenged surviving fishes were anaesthetized by immersing the fish in water containing $50 \mu \mathrm{L} / \mathrm{L}$ of clove oil. Blood samples were collected from the caudal vein of fish, by using needles previously rinsed in heparin for the hematological evaluation. For the plasma separation, the blood samples were centrifuged at $300 \mathrm{xg}$ for $10 \mathrm{~min}$ and the plasma was collected. The plasma was stored at $-20^{\circ} \mathrm{C}$ in microtubes until its use for biochemical and immune studies. After blood collection, the animals (unchallenged and challenged surviving fishes) were killed by anesthetic deepening and tissue samples were removed to biochemical analyses.

\section{Hematological parameters}

Blood collected with anticoagulant was used to measure the hematocrit percentage. The hemoglobin $(\mathrm{Hb})$ concentrations were estimated througha colorimetric kit (Bioclin, Belo Horizonte, Minas Gerais, Brazil) following the manufacturer's instructions. Red blood cells (RBC) were counted in Neubauer chamber. ForWhite blood cells (WBC), total thrombocytes number and total leucocytes number, blood smears were stained with a combination of Giemsa/MayGrunwald (Rosenfeld, 1947) in which two thousand cells were counted to determine the total cell percentage. For the differential leucocytes count, the specific cell percentages were expressed considering the total leucocytes count. Mean corpuscular volume (MCV), mean corpuscular $\mathrm{Hb}(\mathrm{MCH})$, and mean corpuscular $\mathrm{Hb}$ concentration ( $\mathrm{MCHC}$ ) were calculated using standard formulas.

\section{Lysozyme levels}

The serum lysozyme levels were measured spectrophotometrically according to the method of Ellis (1990) with modifications (Villamil et al., 2002). A $0.5 \mathrm{mg} / \mathrm{mL}$ suspension of Micrococcus lysodeikticus (Sigma, Inc, USA) made up in 0.04M phosphate buffer $(\mathrm{pH}$ 6.2) was used as substrate. Lyophilized hen egg white lysozyme $(100 \mu \mathrm{g} / \mathrm{mL})$ (Sigma, Inc, USA) in 0.04M phosphate buffer ( $\mathrm{pH}$ 6.2) was used as a standard. A new calibration curve $(100,50,40,30,20,15,12.5$,
$10,7.5,5,2.5$ e $0 \mu \mathrm{g} / \mathrm{mL}$ ) was prepared for each assay. The plasma samples and the calibration curve $(30 \mu \mathrm{L})$ were incubated for 2 minutes in a microplate reader (Multiskan Go - Thermo Scientific, San Jose, CA, USA) at $35^{\circ} \mathrm{C}$ and $200 \mu \mathrm{L}$ Micrococcus lysodeikticus suspension $(0.5 \mathrm{mg} / \mathrm{mL})$ was added to complete $230 \mu \mathrm{L}$ of final volume. Difference between the initial and final turbidity (optical density (OD) reduction) was measured for $30 \mathrm{~min}$ (30 seconds of intervals) at $492 \mathrm{~nm}$. The linear regression equation of lysozyme calibration curve was used to determine the plasma lysozyme levels $(\mu \mathrm{g} / \mathrm{mL})$.

\section{Quantification of nitrate/nitrite levels}

Quantification of the nitric oxide products in the plasma samples of the fishes was carried out according to the methodology described by Green et al. (1982). Plasma samples $(0.1 \mathrm{~mL})$ were transferred to 96 -well microplate, and vanadium chloride $0.05 \mathrm{M}(0.1 \mathrm{~mL})$ in $\mathrm{HCl} 1.0 \mathrm{M}$ was added to reduce nitrate to nitrite. Immediately, Griess reagent $(50 \mu \mathrm{L}$ of naphthylethylendiamide dihydrochloride $(0.1 \%)$ in $\mathrm{H} 2 \mathrm{O}$ and sulphanilamide $1 \%(50 \mu \mathrm{L})$ in $\mathrm{HCl} 5 \%$, vol. 1:1) was added. After incubation at $37^{\circ} \mathrm{C}$ for 40 min, nitrite concentrations expressed as $\mu \mathrm{M}$ were estimated by interpolation from a standard curve of sodium nitrite $(0-150 \mu \mathrm{M})$ by colorimetric measurements at 540 $\mathrm{nm}$ in a microplate reader (Multiskan Go - Thermo Scientific, San Jose, CA, USA) (Villamil, Tafalla, Figueras \& Novoa, 2002; Miranda, Espey \& Wink, 2001).

\section{Biochemical parameters}

For the biochemical parameters, plasma samples and tissues homogenates were used. The liver, muscle, kidney and spleen tissues were homogenized in phosphate buffered saline (PBS), $\mathrm{pH}$ 7.2. The homogenates were centrifuged at $5000 \mathrm{xg}$ for $10 \mathrm{~min}$ to eliminate nuclei and cell debris, and the supernatant fraction obtained was frozen at $-70^{\circ} \mathrm{C}$ for further measurements. The protein levels were estimated spectrophotometrically using the method described by Bradford (1976), and bovine serum albumin was used as the standard.

Plasma glucose levels were determined by the glucose oxidase method through commercial colorimetric kits (Gold Analisa $\AA$, Belo Horizonte, MG, Brazil) following the manufacturer's instructions. The liver and muscle glycogen content were determined as described by Krisman (1962).

The enzymatic activity of aspartate aminotransferase (AST) and alanine aminotransferase (ALT) was quantified in aliquots of plasma and tissues homogenates (liver, muscle) by using the colorimetri c method. Results for the enzyme activities were 
obtained by using calibration curves based on nonchromogenic absorbance. The absorbance of the samples was determined in microplate reader (Multiskan Go - Thermo Scientific, San Jose, CA, USA) at $505 \mathrm{~nm}$. The results for tissues and plasma were expressed as $\mathrm{U} / \mathrm{L} / \mathrm{mg}$ protein or $\mathrm{U} / \mathrm{L}$, respectively.

The supernatants from the tissues homogenates were used for analyses of thiobarbituricacid reactive substances (TBARS) and catalase (CAT). CAT activity was determined at $240 \mathrm{~nm}$ by using the method described by Aebi (1984) and the results were reported as $\mathrm{mmol} / \mathrm{mg}$ protein/min. Lipid peroxidation was measured by thiobarbituric acid reactive substances (TBARS) using the method described by Federici, Shaw \& Handy (2007) and the results were reported as nmol MDA/mg protein.

\section{Data and statistical analysis}

Data were expressed as mean \pm SD. Bartlett and Shapiro-Wilk tests were used to determine the homogeneity of the variance and normality, respectively. One-way analysis of variance (ANOVA) and Tukey test were used to verify significance of the mean differences among treatments. The minimum significance level was set at $p<0.05$. All tests were performed with the Software RStudio 0.99.896.

\section{RESULTS AND DISCUSSION}

\section{Growth performance and biochemical parameters}

During the acclimation and the experimental periods, the dissolved oxygen $(4.8 \pm 0.58 \mathrm{mg} / \mathrm{L})$, temperature $\left(27.22 \pm 0.6^{\circ} \mathrm{C}\right), \mathrm{pH}(7.08 \pm 0.19)$, salinity $(2.02 \pm 0.17 \%$ o), total ammonia $(0.37 \pm 0.35 \mathrm{mg} / \mathrm{L})$ and nitrite levels $(0.108 \pm 0.105 \mathrm{mg} / \mathrm{L})$ remained constant and close to the reference levels for $\mathrm{R}$. quelen (Baldisserotto, 2013).

As indicated in table 1, there was no difference in terms of weight gain and growth parameters among the fish fed with garlic-supplemented diets and the control group. It has been shown that effects of garlic supplemented diets on growth parameters of different fishes were influenced by the concentrations used and the treatments period (Bard et al., 2006; Diab et al., 2008; Shalaby et al., 2006) being observed improvement of weight gain and growth rates with higher concentrations of garlic in the diets (Shalaby et al., 2006). In terms of weight gain and growth rates, different conditions such as the fish species, treatment periods and development stages of the animals seems to be determinant to the results of the garlic supplementation.

It is well known that the metabolic and nutritional conditions of an animal can influence their growth,
Table 1. Growth parameters of R. quelen juveniles fed on diets containing different levels of garlic extract.

\begin{tabular}{lcccc}
\hline \multirow{2}{*}{ Parameters } & \multicolumn{4}{c}{ Garlic extracts (\%) } \\
\cline { 2 - 5 } & Control & 0.5 & 2.5 & 5 \\
\hline IW (g) & $9.17 \pm 2.18$ & $9.71 \pm 1.92$ & $9.15 \pm 1.60$ & $10.13 \pm 2.64$ \\
FW (g) & $61.62 \pm 24.75$ & $49.04 \pm 21.02$ & $38.52 \pm 13.88$ & $49.37 \pm 13.51$ \\
\hline Weight gain (\%) & 572.2 & 402.9 & 321.2 & 387.5 \\
\hline SL (cm) & $8.43 \pm 0.69$ & $8.57 \pm 0.54$ & $8.35 \pm 0.73$ & $8.55 \pm 0.88$ \\
FSL (cm) & $14.98 \pm 2.12$ & $14.00 \pm 2.18$ & $12.94 \pm 1.74$ & $14.00 \pm 1.31$ \\
\hline Standard growth rate (\%) & 77.78 & 63.40 & 54.94 & 63.74 \\
\hline ITL (cm) & $10.09 \pm 0.83$ & $10.34 \pm 0.76$ & $10.09 \pm 0.81$ & $10.43 \pm 0.99$ \\
FTL (cm) & $17.78 \pm 2.25$ & $16.56 \pm 2.53$ & $15.31 \pm 1.90$ & $16.80 \pm 1.53$ \\
\hline Total growth rate (\%) & 76.27 & 60.10 & 51.73 & 61.05 \\
\hline Data expressed as mean \pm SD. P<0.05. n=10. IW (initial weight). FW (final weight).
\end{tabular}

SL (initial standard length). FSL (final standard length). ITL (initial total length). FTL

(final total length).

immune responses and resistance. The figure 1 shows the effect of garlic supplementation on glycemia and muscle and liver glycogen levels. As it can be seen, the garlic-supplemented diets did not significantly modify the R. quelen blood glucose levels compared with the control group during the period studied. Additionally, the garlic supplementation at $2.5 \%$ significantly increased muscle glycogen content without interfere with the liver glycogen levels (Figure 1B, 1C). The glycemic levels in different fish species can be used to evaluate the health conditions of the fishes as well as to estimate the fishes' capacity to react and adapt to stress conditions. The garlic supplementation in fishes is closely related with significant reductions in glycemia, especially when using higher garlic concentrations (Shalaby et al., 2006; Talpur \& Ikhwanuddin, 2012). In the present study, the absence of modifications on blood glucose levels and on liver glycogen content suggests that the garlic supplementation did not interfere on glucose homeostasis of $\mathrm{R}$. quelen considering the period of supplementation used herein although it has potential to stimulate muscle glycogen deposition, increasing the energy source for muscle cells according to other species tested.

Besides carbohydrate metabolism, we investigated whether the garlic supplementation could affect amino acids metabolism in R. quelen. As it can be seen on figures 2 and 3 there were no alterations of AST and ALT activities in different tissues such as liver and muscle as well as at the blood stream. This result correlates with the fact that garlic did not stimulate neither weight gain nor growth of the $\mathrm{R}$. quelen in the period studied (Table 1). 
$\mathbf{A}$
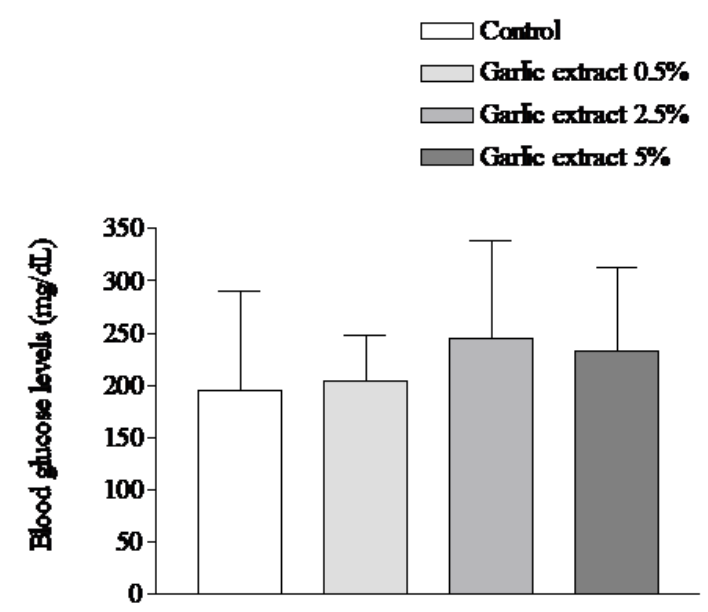

B

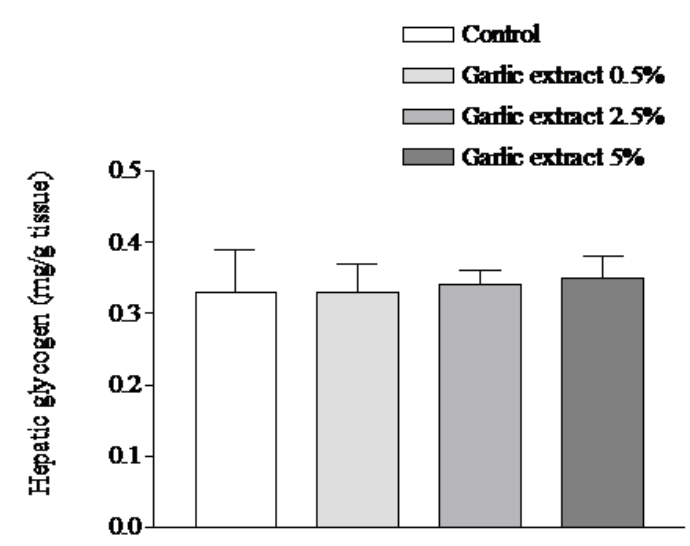

C

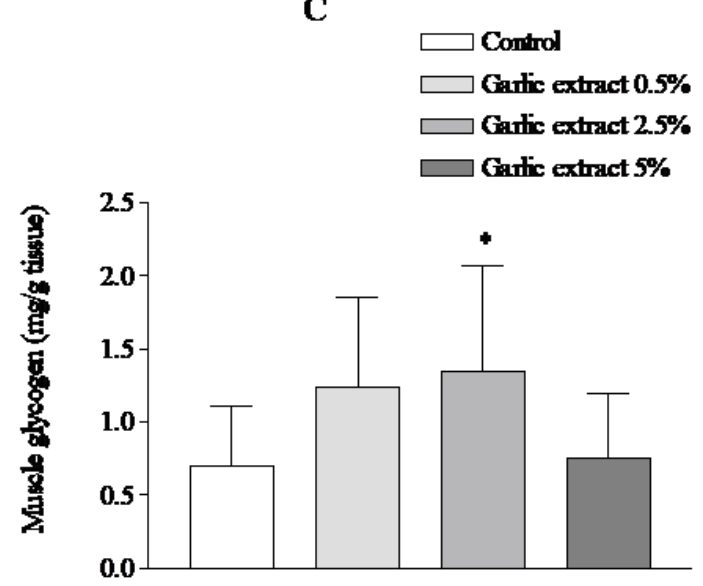

Figure 1. Effect of garlic extracts $(0.5,2.5$ and $5 \%)$ on blood glucose levels (A) and on hepatic (B) and muscle (C) glycogen content from $R$. quelen. Values are expressed as mean $\pm S D ; n=10$. Significant at ${ }^{*} p \leq 0.05$ in relation to control group.
A

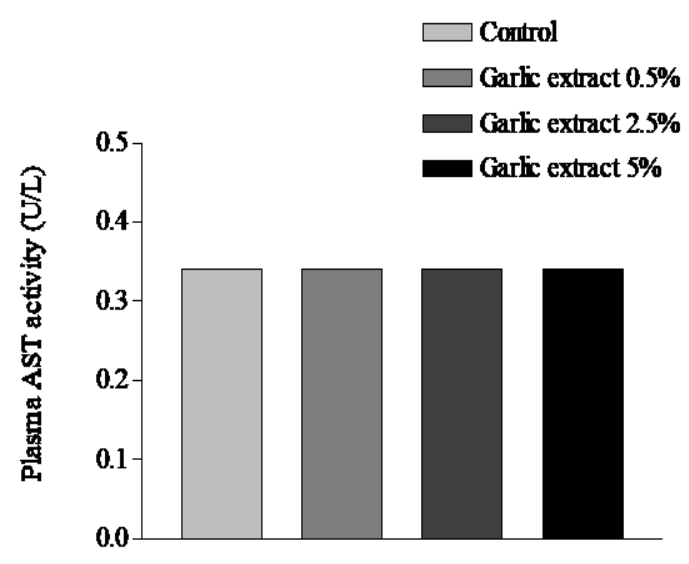

B

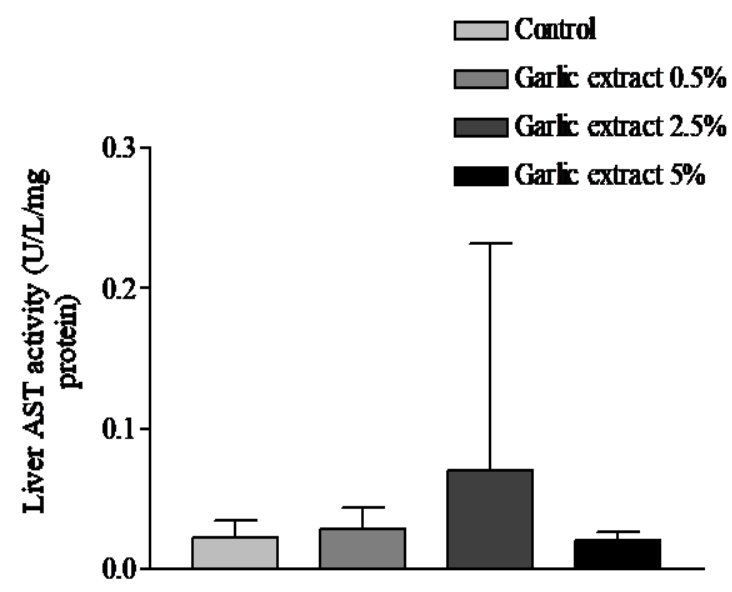

C

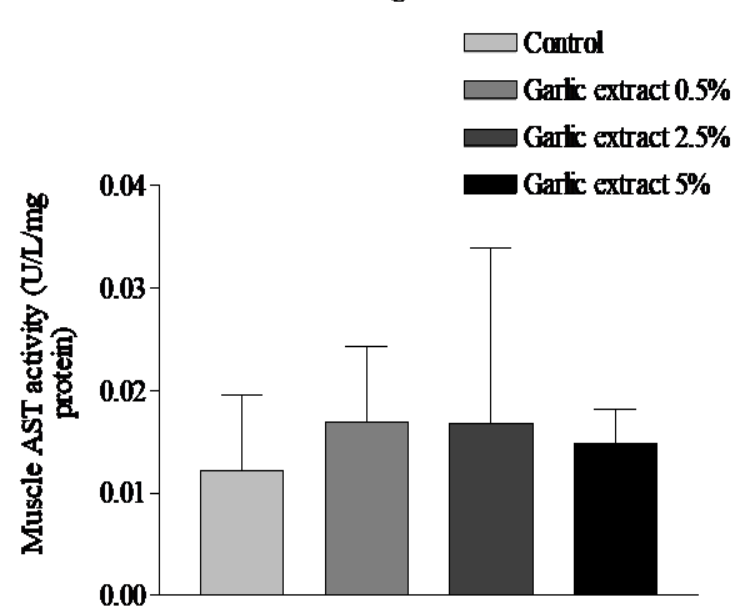

Figure 2. Effect of garlic extracts $(0.5,2.5$ and $5 \%)$ on aminotransferase (AST) activity on R. quelen plasma (A), liver (B), muscle $(C)$. Values are expressed as mean $\pm S D ; n=10$. 
A

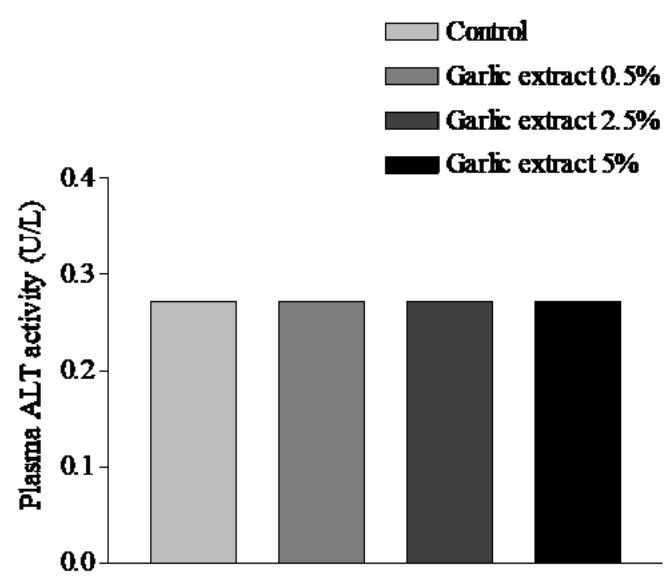

B

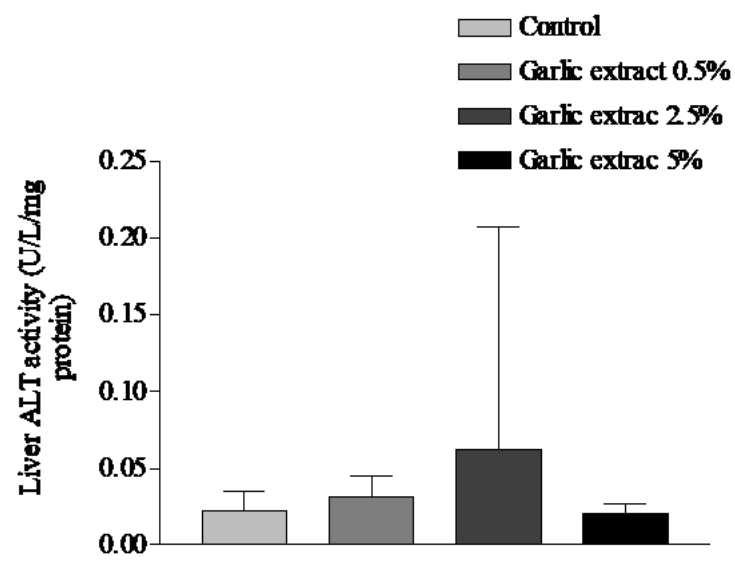

C

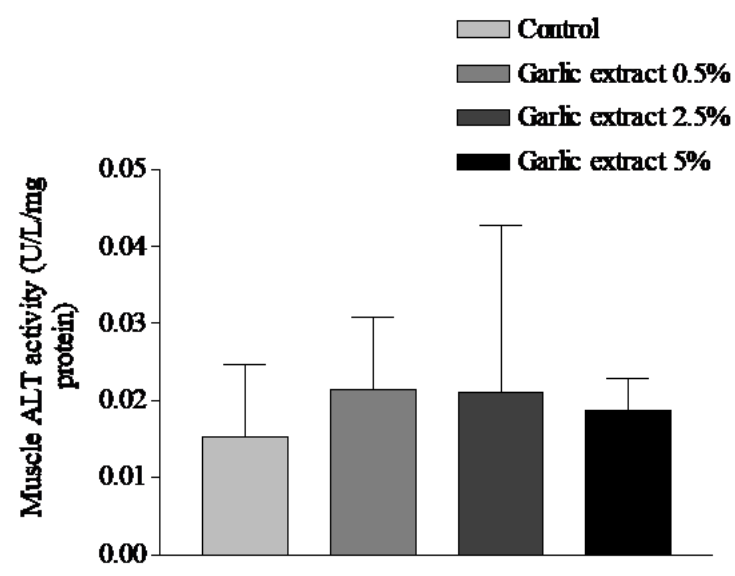

Figure 3. Effect of garlic extracts $(0.5,2.5$ and $5 \%)$ on aminotransferase (ALT) activity on R. quelen plasma (A), liver (B), muscle $(C)$. Values are expressed as mean $\pm S D ; n=10$.
As these enzymes are directly involved in the metabolism of amino acids and indirectly in the amino acids disponibility to the protein metabolism and they are commonly used as indicators of tissues lesions or acute toxicity (Jürss \& Bastrop, 1995), these results suggest that the supplementation did not alter the normal physiology of R. quelen in relation to amino acid metabolism and show no liver damage.

In addition, it has already been proven that garlic supplementation improves the antioxidant status and the body homeostasis in different in vivo and in vitro experimental models (Borek, 2001; Wilson \& Demmig-Adams, 2007). In order to characterize the antioxidant effects of garlic supplementation in R. quelen, we studied the catalase activity and the lipoperoxidation levels in different tissues. As shown in tables 2 and 3 , just the $2.5 \%$ garlic supplemented diet significantly decreased the catalase activity in the liver of silver catfish compared to the control group, without any other modifications neither in catalase activity nor in the lipoperoxidation levels for any treatment. It is important to note that this is the first report about the influence of supplementation with garlic extract for $R$. quelen and the evaluation of the antioxidant status. It has been demonstrated that the antioxidant properties of garlic could be useful for fishes since the improvement of the antioxidant status and consequently the global health conditions would help the animals to improve their capacity of responsiveness to environmental aggressors such as pathogens or stress during the cultivation (Lee \& Gao, 2012) although this effect was not observed in our experimental conditions for silver catfish.

Table 2. Effect of garlic extracts $(0.5,2.5$ and $5 \%)$ on catalase activity ( $\mathrm{mmol} \mathrm{H} 2 \mathrm{O} 2 / \mathrm{mq}$ protein/min) in R. quelen liver, kidnev and spleen.

\begin{tabular}{lcccc}
\hline $\begin{array}{l}\text { Catalase activity } \\
\text { (mmol } \mathrm{H}_{2} \mathrm{O} / \mathrm{mg}\end{array}$ & \multicolumn{4}{c}{ Garlic extracts (\%) } \\
\cline { 2 - 5 } protein/min) & Control & 0.5 & 2.5 & 5 \\
\hline Liver & $0.24 \pm 0.06$ & $0.26 \pm 0.06$ & $0.17 \pm 0.08^{*}$ & $0.21 \pm 0.05$ \\
Kidney & $0.06 \pm 0.02$ & $0.07 \pm 0.04$ & $0.06 \pm 0.02$ & $0.08 \pm 0.03$ \\
Spleen & $0.03 \pm 0.02$ & $0.03 \pm 0.03$ & $0.03 \pm 0.01$ & $0.02 \pm 0.02$ \\
Values are expressed as mean $\pm \mathrm{SD} ; \mathrm{n}=10$. &
\end{tabular}

Table 3. Effect of garlic extracts $(0.5,2.5$ and $5 \%)$ on lipoperoxidation levels (nmol MDA/mg protein) in R. quelen liver, kidney, spleen and muscle.

\begin{tabular}{lcccc}
\hline Lipoperoxidation & \multicolumn{4}{c}{ Garlic extracts (\%) } \\
\cline { 2 - 5 } (nmol MDA/mg & & & \\
protein) & Control & 0.5 & 2.5 & 5 \\
\hline Liver & $0.0272 \pm 0.0003$ & $0.0273 \pm 0.0001$ & $0.0271 \pm 0.0002$ & $0.0275 \pm 0.0003$ \\
Kidney & $0.0237 \pm 0.0003$ & $0.0236 \pm 0.0002$ & $0.0235 \pm 0.0002$ & $0.0238 \pm 0.0003$ \\
Spleen & $0.0031 \pm 0.0019$ & $0.0026 \pm 0.0006$ & $0.0028 \pm 0.0016$ & $0.0026 \pm 0.0011$ \\
Muscle & $0.0114 \pm 0.0003$ & $0.0116 \pm 0.0005$ & $0.0116 \pm 0.0005$ & $0.0113 \pm 0.0002$
\end{tabular}

Values are expressed as mean $\pm S D ; n=10$. 


\section{Hematological and immune responses}

The effects of dietary garlic extract on R. quelen hematological parameters are presented in table 4. The number of erythrocytes (RBC) from the groups that received garlic supplemented diets was significantly higher $(p<0.05)$ than the control group. The highest number of erythrocytes $(2,31 \pm$ $0,93 \%$ ) was observed in the group that received $2.5 \%$ garlic-added diet. On the other hand, the hemoglobin $\mathrm{Hb}$ content was significantly reduced in the treatment with $5 \%$ of garlic extract compared with the control and treatment groups, while the hematocrit (Hct) did not vary significantly from the values observed for the control group $(p>0.05)$. It was already demonstrated that changes in hematological variables are important to the assessment of fish health (Blaxhall, 1972) and to monitor stress responses (Roche \& Bogé, 1996; Bonga, 1997). According to Ranzani-Paiva \& Silva-Souza (2004), changes in the hematological parameters of fish can be observed when they are infected by pathogens or subjected to stress, or when their food is changed.

Table 4. Effect of garlic extracts $(0.5,2.5$ and $5 \%)$ on hematological parameters from R. quelen juveniles.

\begin{tabular}{|c|c|c|c|c|}
\hline \multirow[b]{2}{*}{ Parameters } & \multicolumn{4}{|c|}{ Garlic extracts (\%) } \\
\hline & Control & 0.5 & 2.5 & 5 \\
\hline $\mathrm{RBC}\left(10^{6} / \mu \mathrm{L}\right)$ & $1.51 \pm 1.67$ & $1.81 \pm 2.29^{*}$ & $2.31 \pm 0.93^{\star}$ & $1.80 \pm 2.93^{*}$ \\
\hline Hct (\%) & $29.2 \pm 5.2$ & $28.5 \pm 6.4$ & $24.7 \pm 5.7$ & $27.9 \pm 4.7$ \\
\hline $\mathrm{Hb}(\mathrm{g} / \mathrm{dL})$ & $6.56 \pm 0.69$ & $6.61 \pm 1.60$ & $6.24 \pm 1.48$ & $3.66 \pm 1.47^{\star \#}$ \\
\hline $\mathrm{MCV}$ (fL) & $194.32 \pm 32.84$ & $161.29 \pm 42.22$ & $119.56 \pm 53.54^{*}$ & $168.11 \pm 42.54$ \\
\hline $\mathrm{MCH}(\mathrm{pg})$ & $43.92 \pm 6.52$ & $37.00 \pm 11.01$ & $29.73 \pm 8.93$ & $22.98 \pm 11.90^{\star}$ \\
\hline $\mathrm{MCHC}(\mathrm{g} / \mathrm{dL})$ & $22.87 \pm 2.99$ & $22.88 \pm 2.41$ & $27.69 \pm 11.02$ & $14.12 \pm 7.29^{\star}$ \# \\
\hline \multicolumn{5}{|c|}{$\begin{array}{l}\text { Variables are red blood cell count (RBC), hemoglobin }(\mathrm{Hb}) \text { concentration, } \\
\text { hematocrit }(\mathrm{Hct}) \text {, mean corpuscular volume }(\mathrm{MCV}) \text {, mean corpuscular } \mathrm{Hb}(\mathrm{MCH}) \text {, }\end{array}$} \\
\hline & & & & \\
\hline
\end{tabular}

In addition, the blood indices calculated from the mean values of blood parameters shows that MCV was significantly reduced in $2.5 \%$ treatment compared to the control group. In addition, $\mathrm{MCH}$ and $\mathrm{MCHC}$ were significantly reduced in $\mathrm{R}$. quelen fed on diets containing $5 \%$ of garlic compared with the control group. The MCHC was also significantly reduced when compared with the other treatment groups $(0.5$ and $2.5 \%)$. These results suggest that the animals from the $5 \%$ garlic treatment developed anemia at the end of the experiment and probably presented an impairment of the oxygen transport capacity and consequently of the metabolic function of the tissues. Earlier studies demonstrated that low garlic concentrations such as $0.05 \%$ to $3 \%$ resulted in hematological improvements in fishes (Nya \& Austin, 2009; Talpur \& Ikhwanuddin, 2012). However, higher concentrations $(4 \%$ and $6 \%)$ resulted in significant decreases in blood parameters leading to anemia probably due to the inhibition of RBCs (erythropoiesis) and heme synthesis or an increased rate of erythrocyte destruction in hematopoietic organs (Çelik et al., 2013; Irkin et al., 2014).

As part of the hematological system, the immune responses are important defense mechanisms to protect the animal body against infection and to maintain homeostasis. In the present study, there were no significant changes on the total leucocytes and thrombocytes count as well as at the differential count compared to the control group as shown in table 5 . These results agree with a previous study where R. quelen received garlic supplemented diets $(3,6$, 9 e $12 \mathrm{~g} / \mathrm{kg}$ ) and no significant alterations on WBC (leucocytes) cells were observed (Bard et al., 2006).

Additionally, it was observed significant reductions in the monocytes and basophils counts for the $0.5 \%$ treatment group compared with the 2.5 and $5 \%$ treatments and the control groups. The reduction in monocytes count, observed in the present study, suggests that the garlic supplementation may lead to an impairment of the non-specific immune responses of $R$. quelen, since this type of cell is involved in phagocytosis and inflammatory responses (Rieger \& Barreda, 2011).

On the other hand, the basophils count was significantly increased in 2.5 and $5 \%$ garlic supplemented diet compared with the control group and the $0.5 \%$ treatment group. The increase in basophils count is correlated with the increase in garlic concentrations suggesting that more careful studies should be performed to state precisely the real effectiveness of garlic as immunostimulant as well as to investigate a potential allergenic role of garlic in R. quelen. During phagocytosis, after leukocytes diapedesis and chemotaxis to the lesion, the leukocytes recognize, phagocyte and degrade pathogens (Rieger \& Barreda, 2011). Lysozyme available in the lysosomes of neutrophils and macrophages, is known to act as a nonspecific immune mediator against parasitic, bacterial and viral infections (Lie et al., 1989; Saurabh \& Sahoo, 2008). In the present study, the serum lysozyme levels were not influenced by garlic supplemented diets throughout the experimental period (Figure 4). Additionally, when phagocytosis is initiated, there is an increase in the production of reactive oxygen and nitrogen species which are powerful microbicidal agents. Activated macrophages release nitric oxide (NO) (Rieger \& Barreda, 2011) which has been shown to have potent antimicrobial effects against a number of relevant fish pathogens, especially bacteria, although the role of $\mathrm{NO}$ in fish parasitic infections and its effect on pathogen 
viability remains less known (Campos-Perez et al., 2000; Forlenza et al., 2008; Rieger \& Barreda, 2011). Since plasma NO released from the cells rapidly auto oxidizes to yield the stable metabolites of NO (nitrite/ nitrate), the level of nitrite/nitrate in blood may be an indicator of endogenous NO production (Miranda et al., 2001). As it can be seen in figure 5, the nitrite/ nitrate plasma levels were not affected by the garlic treatments compared with the control group. It is important to note that, although garlic is considered an immunostimulant, it was not able to change R. quelen non-specific immune parameters such as lysozyme and nitrite/nitrate plasma levels in the experimental conditions of this study. These results corroborate the fact that garlic evoked a reduction in the monocytes count after the treatments (Table 5), which suggests that in the concentrations used herein garlic did not stimulate immune responses in R. quelen.

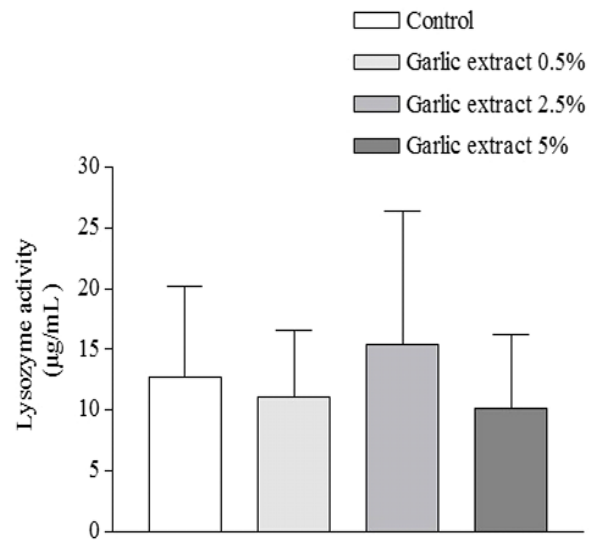

Figure 4. Effect of garlic extracts $(0.5,2.5$ and $5 \%)$ on R. quelen plasma lysozyme levels. Values are expressed as mean $\pm S D ; n=10$.

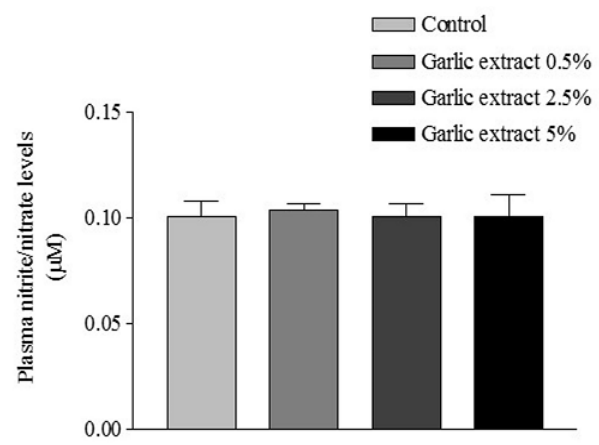

Figure 5. Effect of garlic extracts $(0.5,2.5$ and $5 \%)$ on R. quelen plasma nitrate/nitrite levels. Values are expressed as mean $\pm \mathrm{SD}$; $\mathrm{n}=10$.

\section{Challenge test}

The relative survival and mortality percentages of $\mathrm{R}$. quelen after the challenge with $\mathrm{I}$. multifiliis in experimental groups are shown in table 6. As it can be seen, none of the garlic supplemented diets were able to improve $\mathrm{R}$. quelen resistance to I. multifiliis infection after $72 \mathrm{~h}$ of the challenge. Although Allium sativum has been shown promising results when tested in vitro for I. multifiliis (Buchmann et al., 2003), when incorporated in feed and tested in vivo this extract was not able to significantly reduce infection levels when compared to control groups (PicónCamacho et al., 2012). Additionally, the challenge with I. multifiliis induced characteristic histological changes at the gills and skin of the fishes and the treatments with garlic were not able to protect the animals against the parasite infestation (data not shown).

Table 5. Effect of garlic extracts $(0.5,2.5$ and $5 \%)$ on white blood cells (WBC), thrombocytes and differential count of leukocytes from R. quelen juveniles' blood.

\begin{tabular}{|c|c|c|c|c|}
\hline \multirow[b]{2}{*}{ Parameters (\%) } & \multicolumn{4}{|c|}{ Garlic extracts (\%) } \\
\hline & Control & 0.5 & 2.5 & 5 \\
\hline Thrombocytes & $2.63 \pm 1.12$ & $2.17 \pm 0.54$ & $2.20 \pm 0.54$ & $2.70 \pm 0.85$ \\
\hline WBC & $3.78 \pm 1.55$ & $2.60 \pm 1.13$ & $3.67 \pm 0.28$ & $3.74 \pm 0.64$ \\
\hline Limphocytes & $41.66 \pm 19.36$ & $53.04 \pm 2.68$ & $46.95 \pm 14.84$ & $65.57 \pm 13.36$ \\
\hline Immature cells & $4.63 \pm 2.236$ & $3.11 \pm 2.68$ & $2.48 \pm 1.89$ & $2.80 \pm 1.92$ \\
\hline Neutrophils & $31.06 \pm 15.50$ & $34.65 \pm 13.04$ & $28.97 \pm 10.94$ & $15.84 \pm 6.91$ \\
\hline Monocytes & $21.18 \pm 10.30$ & $8.12 \pm 6.48^{* \#}$ & $15.78 \pm 9.54$ & $9.95 \pm 6.37$ \\
\hline Basophils & $1.47 \pm 3.49$ & $1.08 \pm 1.56^{\#}$ & $5.88 \pm 4.12^{\star @}$ & $5.84 \pm 3.53^{*} @$ \\
\hline
\end{tabular}

Table 6. Effect of garlic extracts $(0.5,2.5$ and $5 \%)$ on survival and mortality rates of $\mathrm{R}$. quelen following I. multifilis challenge.

\begin{tabular}{lcccc}
\hline & \multicolumn{5}{c}{ Garlic extracts (\%) } \\
\cline { 2 - 5 } & Control & 0.5 & 2.5 & 5 \\
\hline Survival rate (\%) & 30 & 20 & 10 & 10 \\
Mortality rate (\%) & 70 & 80 & 90 & 90 \\
\hline
\end{tabular}

\section{CONCLUSIONS}

In the present study, garlic supplemented diets did not act as a growth promoter and did not modified the biochemical profile, the survival rate and the $\mathrm{R}$. quelen resistance to the challenge infestation with I. multifillis during the period of supplementation. It is important to address that the present study is the first attempt to examine the effects of dietary garlic supplementation on the hematological, immune and biochemical status of R. quelen.

Additionally, the garlic potential as immunostimulantseems to be dependentof dose, period of treatment and the development stage of the animals. Thus, further studies are necessary to determine the optimal application frequency for favorable garlic performance and to assess its impacts on parasitic infestation levels and animal's resistance. 


\section{ACKNOWLEDGMENT}

This work was supported by grants from "Conselho Nacional de Desenvolvimento e Tecnológico (CNPq)" MCTI/MAPA/MDA/MEC/MPA/CNPq N ${ }^{\circ}$ 81/2013.

\section{CONFLICT OF INTEREST STATEMENT} of interest.

The authors declare that there are no conflicts

\section{REFERENCES}

Aebi, H. 1984. Catalase in vitro, Meth. Enzymol. 105, 121-126.

Baldisserotto, B. 2013. Crescimento. In: Baldisserotto B. (Ed), Fisiologia de peixes aplicada à piscicultura. Santa Maria, pp. 152-321.

Bard, J.J.; Boscolo, W.R.; Maluf, M.L.F.; Feiden, A.; Reidel, A.; Mahl, I.; Signor, A.A. 2006. Análise hematológica de alevinos de jundiá (Rhamdia quelen) submetidos a dieta alimentar com diferentes níveis de inclusão de alho (Allium sativum). In: I Simpósio Nacional de Engenharia de Pesca e III Simpósio Paranaense de Engenharia de Pesca. Toledo, PR, Brazil, pp. 6.

Blaxhall, P.C. 1972. The hematological assessment of the health of freshwater fish. A review of selected literature. J. Fish. Biol., 4, 593-604.

Bonga, S.E.W. 1997. The stress response in fish. Physiol. Rev., 77, 591- 625.

Borek, C. 2001. Antioxidant health effects of aged garlic extract, J. Nutr., 131, 1010-1015.

Bradford, M. 1976. A rapid and sensitive method for the quantification of microgram quantities of protein utilizing the principle of protein-dye binding, Anal. Biochem., 72, 248-254.

Buchmann, K.; Jensen, P.B.; Kruse, K.D. 2003. Effects of sodium percarbonate and garlic extract on Ichthyophthirius multifiliis theronts and tomocysts: in vitro experiments. North Am. J. Aquacult., 65, 21-24.

Campos-Perez, J.J.; Ellis, A.E.; Secombes, C.J. 2000. Toxicity of nitric oxide and peroxynitrite to bacterial pathogens of fish. Dis. Aq. Org., 43, 109-115.

Çelik, E.; Kaya, H.; Yilmaz, S.; Akbulut, M.; Tulgar, A. 2013 Effects of zinc exposure on the accumulation, haematology and immunology of Mozambique tilapia, Oreochromis mossambicus. Afr. J. Biotech., 12, 744-753.

Diab, A.S.; Aly, S.M.; John, G.; Abde-Hadi, Y.; Mohammed, M.F. 2008. Effect of garlic, black seed and Biogen as immunostimulants on the growth and survival of Nile tilapia, Oreochromis niloticus
(Teleostei: Cichlidae), and their response to artificial infection with Pseudomonas fluorescens. Afr. J. Aq. Sci., 33, 63-68.

Dotta, G.A.; Andrade, J.I.; Tavares Gonçalves, E.L.; Brum, A.; Mattos, J.J.; Maraschin, M.; Martins, M.L. 2014. Leukocyte phagocytosis and lysozyme activity in Nile tilapia fed supplemented diet with natural extracts of propolis and Aloe barbadensis, Fish Shellf. Immunol., 39, 280-284.

Ellis, A.E. 1990. Lysozyme assays. In: Stolen JS, Fletcher TC, Anderson DP, Roberson BS, Muiswinkel WB, (Eds). Techniques in Fish Immunology, USA.

FAO. El estado mundial de la pesca y la acuicultura 2018. Cumplir los objetivos de desarrollo sostenible. Roma, 2018.

Federici, G.; Shaw, B.J.; Handy, R.D. 2007. Toxicity of titanium dioxide nanoparticles to rainbow trout (Oncorhynchus mykiss): gill injury, oxidative stress, and other physiological effects. Aq. Toxicol., 84, 415-430.

Forlenza, M.; Scharsack, J.P.; Kachamakova, N.M.; Taverne-Thiele, A.J.; Rombout, J.H.; Wiegertjes, G.F. 2008. Differential contribution of neutrophilic granulocytes and macrophages to nitrosative stress in a host-parasite animal model. Mol. Immunol., 45, 3178-3189.

Green, L.C.; Wagner, D.A.; Glogowski, J.; Skipper, P.L.; Wishnok, J.S.; Tannenbaum, S.R. 1982. Analysis of nitrate, nitrite and [15N] nitrate in biological fluids, Anal. Biochem., 126, 131-138.

Hai, N.V. 2015. The use of medicinal plants as immunostimulants in aquaculture: A review. Aquaculture, 446, 88-96.

Irkin, L.C.; Yigit, M.; Yilmaz, S.; Maita, M. 2014. Toxicological evaluation of dietary garlic (Allium sativum) powder in European sea bass Dicentrarchus labrax juveniles, Food Nutr. Sci., 5, 989-996.

Jürss, K.; Bastrop, R. 1995. Amino acid metabolism in fish. In: Mommsen TP, Hochachka P, (Eds.), Biochemistry and molecular biology of fishes, USA.

Krisman, C.R. 1962. A method for the colorimetric estimation of glycogen with iodine, Anal. Biochem., 4, 17-23.

Lawson, L.D. 1998. Garlic: A review of its medicinal effects and indicated active compounds. ACS Symp Ser, 14, 176-209.

Lee, J.Y.; Gao, Y. 2012. Review of the Application of Garlic, Allium sativum, in Aquaculture. J. World Aquacult. Soc., 43, 447-458.

Lie, O.; Evensen, O.; Sorensen, A.; Froysadal, E. 1989. Study on lysozyme activity in some fish species. Dis. Aq. Org., 6, 1-5.

Miranda, K.M.; Espey, M.G.; Wink, D.A. 2001. A 
rapid, simple spectrophotometric method for simultaneous detection of nitrate and nitrite, nitric oxide. Biol. Chem., 5, 62-71.

Nya, E.J.; Austin, B. 2009. Use of Garlic, Allium sativum, to Control Aeromonas hydrophila Infection in Rainbow Trout, Oncorhynchus mykiss (Walbaum), J. Fish Dis., 32, 963-970. Infection in Rainbow Trout, Oncorhynchus mykiss (Walbaum), J. Fish Dis., 32, 963-970.

Picón-Camacho, S.M.; Marcos-Lopez, M.; Bron, J.E.; Shinn, A.P. 2012. An assessment of the use of drug and non-drug interventions in the treatment of Ichthyophthirius multifiliis Fouquet, 1876, a protozoan parasite of freshwater fish. Parasitology, 139, 149-190.

Raja, R.A.; Jithendran, K.P. 2015. Aquaculture disease diagnosis and health management, In: Santhanam P, Thirunavukkarasu AR, Pachiappan $P$, (Eds.), Advances in marine and brackishwater aquaculture, India. Springer, 1 ed., Germany.

Rico, A.; Phu, T.M.; Satapornvanit, K.; Min, J.; Shahabuddin, A.M.; Henriksson, P.J.G.; Murray, F.J.; Little, D.C.; Dalsgaard, A.; Van Den Brink, P.J. 2013. Use of veterinary medicines, feed additives and probiotics in four major internationally traded aquaculture species farmed in Asia. Aquaculture, 412-413.

Rieger, A.M.; Barreda, D.R. 2011. Antimicrobial mechanisms of fish leukocytes. Develop. Comp. Immunol., 35, 1238-1245.

Roche, H.; Bogé, G. 1996. Fish blood parameters as a potential tool for identification of stress caused by environmental factors and chemical intoxication. Mar. Env. Res., 41, 27-43.

Rombout, J.H.; Wiegertjes, G.F. 2008. Differential contribution of neutrophilic granulocytes and macrophages to nitrosative stress in a host-parasite animal model. Mol. Immunol., 45, 3178-3189.

Rosenfeld, G. 1947. Corante pancrômico para hematologia e citologia clínica. Nova combinação dos componentes do May-Grunwald e do Giemsa num só corante de emprego rapido. Mem. Inst. But., 20, 329-335.

Saurabh, S.; Sahoo, P.K. 2008. Lysozyme: an important defense molecule of fish innate immune system. Aquacult. Res., 39, 223-239.

Shakya, S.R.; Labh, S.N. 2014. Medicinal uses of garlic (Allium sativum) improves fish health and acts as an immunostimulant in aquaculture. Eur. J. Biotech. Biosci., 2, 44-47.

Shalaby, A.M.; Khattab, Y.A.; Abdel Rahman, A.M. 2006. Effects of garlic (Allium Sativum) and chloramphenicol on growth performance, physiological parameters and survival of Nile
Tilapia (Oreochromis niloticus). J. Ven. Anim. Tox. Includ. Trop. Dis., 12, 172-201.

Souza, V.N.; Martins, M.L.; De Moraes, F.R.; Kronka, S.N. 2001. Metodologia de infecção experimental e grau de susceptibilidade do híbrido "tambacu" e Leporinus macrocephalus Garavello e Britski (Osteichthyes, Anostomidae) a quatro inóculos de trofozoítos de Ichthyophthirius multifiliis Fouquet (Protozoa, Ciliophora). Rev. Bras. Zool., 18, 803-811.

Talpur, A.D.; Ikhwanuddin, M. 2012. Dietary effects of garlic (Allium sativum) on haemato-immunological parameters, survival, growth, and disease resistance against Vibrio harveyi infection in Asian sea bass, Lates calcarifer (Bloch). Aquaculture, v. 364-365, 6-12.

Villamil, L.; Tafalla, C.; Figueras, A.; Novoa, B. 2002. Evaluation of immunomodulatory effects of lactic acid bacteria in turbot (Scophthalmus maximus). Clin. Diag. Lab. Immunol., 9, 1318-1323.

Wei, J.Z.; Li, H.; Yu, H. 2013. Ichthyophthiriasis: emphases on the epizootiology. Let. App. Microbiol., 57, 91-101.

Submetido: Dezembro/19 Revisado: Dezembro/19 Aceito:Dezembro/19 Publicado: $17 / 04 / 20$ 